\title{
The role of women in security Indonesian women peacekeepers in the UNIFIL: Challenges and opportunities
}

\section{Peran perempuan dalam keamanan pasukan pemelihara perdamaian perempuan Indonesia dalam UNIFIL: Tantangan dan peluang}

\author{
Rany Purnama Hadi \& Sartika Soesilowati \\ Department of International Relations, Faculty of Social and Political Sciences, Universitas Airlangga \\ Address: Jalan Dharmawangsa Dalam, Airlangga, Surabaya, East Java 60286 \\ E-mail: ranyphadi@gmail.com
}

\begin{abstract}
Following Security Council Resolution 1325 (2000), the United Nations arranged mandates on women, peace and security (WPS) in order to address the equality between men and women, in order to allow them to actively participate in managing world security and peace. The purpose of this mandate was to give women the same opportunities, protection, access to resources and services, as well as right to participation in decision-making, as an attempt to achieve and sustain peace and security. In 2014, women constituted $3 \%$ of the UN's military personnel and $10 \%$ of the police personnel out of the total number of UN peacekeepers from 123 countries, including Indonesia. In Lebanon, one of the areas focused on by UN peacekeeping missions, Indonesia currently deploys the largest peacekeeping personnel of up to 1,296 individuals, of which 24 are women. This number constitutes 5\% of Indonesia's total peacekeepers on the UN's mission. Using the qualitative approach method through collecting secondary data, this paper aims to examine the participation of Indonesian women peacekeepers, particularly in UNIFIL, in relation to helping, protecting and supporting women and girls as the victims of war based on the feminist point of view. It was found that Indonesian women peacekeepers provide a tremendous contribution to the effectiveness of the UN's peacekeeping operations. Women can provide softer approaches toward war victims and help to promote peace in the region. This shows that women still have not had much opportunity to prove their abilities in battle. Therefore, improvement is needed in order to increase the Indonesian women's peacekeeper role in peacekeeping operations.
\end{abstract}

Keywords: gender; women peacekeeper; security; peace; equality; war; conflict

\begin{abstract}
Abstrak
Dengan disetujuinya Resolusi Dewan Keamanan PBB no 1325 Tahun 2000, PBB secara resmi telah mengeluarkan mandat terhadap perempuan, perdamaian dan keamanan (PPK) guna mewujudkan adanya kesetaraan atas peran laki-laki dan perempuan dalam menjaga perdamaian dan keamanan. Tujuan dari dibentuknya mandate ini adalah untuk memberikan kesempatan yang sama bagi perempuan terkait dengan perlindungan, akses atas sumber daya dan pelayanan, serta partisipasi dalam pembuatan keputusan, sebagai upaya untuk memperoleh dan mempertahankan perdamaian dan keamanan. Di tahun 2014, perempuan menduduki sebanyak 3\% dari total pasukan militer dan 10\% dari personel kepolisian PBB yang terdiri dari 123 negara termasuk Indonesia. Di Lebanon, yang merupakan salah satu area misi perdamaian PBB, Indonesia adalah negara dengan kontribusi terbesar atas pasukan perdamaian hingga mencapai 1296 personel dimana 24 diantaranya adalah perempuan. Jumlah ini setara dengan 5\% dari total personel perdamaian Indonesia di PBB. Menggunakan pendekatan kualitatif melalui proses pengumpulan data sekunder, tulisan ini bertujuan untuk mempelajari partisipasi pasukan pemeliharaan perdamaian wanita Indonesia, khususnya di UNIFIL, dalam perannya untuk membantu dan mendukung perlindungan terhadap perempuan dan anak-anak korban perang, berdasarkan sudut pandang feminisme. Hasil yang ditemukan adalah pasukan pemelihara perdamaian perempuan Indonesia mampu memberikan kontribusi terhadap efektifitas upaya peramaian PBB melalui pendekatan yang lebih halus terhadap para korban perang, dimana hal ini kemudian juga turut membantu menciptakan perdamaian do wilayah konflik. Ini menunjukkan bahwa perempuan masih belum memiliki banyak peluang untuk membuktikan kemampuan mereka dalam pertempuran. Oleh karena itu, perbaikan diperlukan untuk meningkatkan peran penjaga perdamaian wanita Indonesia dalam operasi pemeliharaan perdamaian.
\end{abstract}

Kata kunci: gender; pasukan pemeliharan perdamaian wanita; perdamaian; keamanan; kesetaraan; perang; konflik 


\section{Introduction}

For the first time in the history of the UN, in October 2000, the United Nations Security Council adopted resolution 1325 which stressed the importance of women and their contribution to the prevention and resolution of conflict, peace-building, and peacekeeping (UNSC 2000). This resolution is a landmark in addressing the equal participation needed between men and women in peace and security. Resolution 1325 was not the first treaty or declaration proposed by the UN regarding gender equality. During the 1970s and 1980s, the UN Security Council passed numerous resolutions, declarations and treaties, and also sponsored several conferences on gender issues (Hudson 2005). However, it was not until the Fourth World Conference on Women (FWCW) that was held in Beijing in 1995 that the gender issue had finally gained momentum within the UN. In 2000, UNSC passed a resolution that mainstreaming women being involved in peace and security issues, including peace operations. The resolution also espoused the disproportioned impact of war and armed conflict on women and girls. This reformation in the context of peacekeeping operations has opened up an opportunity for women to be able to be actively involved in maintaining world peace and security.

In a conflict zone, women are always seen of as a weak subject and a victim of war that needs to be protected. Not many realize that women can become leaders both in combat and in postconflict management. Women have a significant part to play in creating peace and in post-conflict construction. They are able to mobilize the masses, building and reintegrating the economy, and they can also serve as a leader in an organization taking care of refugees and displaced persons. In a report by Valerie Norville from the United States Institute of Peace regarding the role of women in global security, it was argued women can act decisively in a conflict zone (Norville 2011). Women can be supporting actors in combat or as people in charge in ensuring the survival of other civilians during conflict. It was also mentioned that the achievement of sustainable peace can be measured by the safety of the women and children in the region. However, this potential is sometimes neglected by society and even by the government.

According to Melanne Verveer, the Head of the State Department's Office for Global Women's Issues (Norville 2011), thirty-one out of thirty-nine active conflicts in the world are recurrences after a peace agreement has been concluded. Out of those thirty-one, women were never involved in the peace building process. It has been proven that the role of women in peace and security is rare. Nonetheless, there is also evidence that women can support and influence the peace process. For example, during the conflict between the Lord's Resistance Army (LRA) and the government of Uganda, women took on the role of supporting the peace negotiations by mobilizing society to suppress both parties, prompting them to conduct peace talks in an attempt to end the conflict. The same happened in 2003 during the conflict in Liberia, where a group of women managed micro-credit groups to help reduce poverty and support the peace process (Norville 2011). In some cases, the United Nations has also been able to show that in most refugee camps, women are always in charge of helping people to fulfill their daily needs and taking care of other refugees. The United Nations aims to espouse the involvement of women in conflict resolution and peace-making. Therefore in October 2000, UN Security Council issued Resolution 1325 in order to engage women more fully in international peacekeeping operations (UNSC 2000).

In 2000, the United Nations made historical changes in its Peacekeeping Operations. This change was as a response to the critics of UN peacekeeping, who no longer considered them as effectively addressing post-conflict management. The UN's peacekeeping operations were considered to be too narrow and ineffective in managing the peacekeeping process, particularly in the case of human violations that have become the main issue of post-cold war conflict. Human violations such as sexual abuse, rape and harassment are some issues that used to be neglected in former UN peacekeeping operations. Therefore, with the implementation of Resolution 1325, the United Nations has tried to improve their peacekeeping operations by entangling the role of women in peacekeeping activities including negotiation, field operation, post-conflict reconstruction, and office duties (United Nations 
2016). This resolution has also changed the structure and mission of peacekeeping, which is now not only about military operations but also institution building, economic development, human rights protection, humanitarian activism, and supervising elections (UN OSAGI 2004).

As a UN member country, Indonesia is also involved in peacekeeping operations, especially in the UNIFIL in which Indonesia is the largest peacekeeping contributor (UNIFIL n.d.). Among its peacekeepers in the UNIFIL, there are 24 women personnel who were deployed in Lebanon with the task of protecting and helping the UN to encourage women and girls to have a better life in Lebanon. The involvement of women as Indonesian peacekeepers shows that Indonesia has tried to improve the role of Indonesian women, encouraging them to participate in managing security and peace as mandated by the UN Security Council Resolution. This commitment has been mentioned under the Foreign Ministry Regulation No. 05/2015 on the Roadmap Vision 4000 Peacekeepers 2015-2019 (Kementerian Luar Negeri Indonesia 2015).

\section{Theoretical framework}

The realm of security and conflict is not an area in which the role of women is commonly considered to be an important aspect (Bendix \& Stanley 2008). When talking about security, people used to aim the focus of the discussion on the occurrence of war, arms violence, and the military. The domination of male and masculine approaches in security studies has created a narrow scope for defining threats to peace and security. However, by the end of the Cold War, the emergence of violent conflict, instability, civil war, human rights violations, and oppression had made the concept of security become more complex and involute. Security no longer means the absence of an arms threat against the state, but also can still be used to refer to a threat towards both humans and the environment. This changing nature of the context of security has created another challenge for peace missions and conflict resolution (Bendix \& Stanley 2008).

In order to analyze the changing nature of security and conflict, it is argued that the role of feminist approaches should be considered in this matter. The concept of security and peace studies are commonly examined through a 'masculine' point of view (Sjoberg 2010). The world sees security and peace studies as being the empire of man. War and conflict have been treated as a man's scope and have only traditionally been operated by men. Before, it was rare for scholars to address gender and women in discussions of security and peace. Regarding this condition, feminist approaches have tried to reformulate and analyze security studies through an exploration of the role of women and gender in conflict and conflict resolution. The feminist approach explains the position of gender and women during conflict, not only how they are seen of as the most prominent victims of violence and rape, but also referring to their participation during and post-conflict (Sjoberg 2010).

In terms of the theoretical framework, feminists are diverse with many perspectives depending on the subject that is being analyzed (Sjoberg 2010). In the realist feminist approach, the subject is in the role of gender and power politics between the different states. Liberal feminists aim to analyze the involvement of women in global politics as a response to gender oppression. Critical feminists and feminist constructivism have different focuses, which are gender identity in relation to global politics and how these ideas shape and are shaped by global politics. Another perspective includes post-structuralism feminist, which is how the gendered linguistics of meanings like strong/weak and rational/emotional constitute the global politics. Although the various frameworks of feminism seem like they have different scopes of interest, all of them have the same purpose - to increase the importance of gender in every aspect of world politics, and not passing over security and conflict.

The development of the feminist perspective in Security Studies has widened the definition of security to becoming more multidimensional. Security is no longer defined merely by war and international conflict, but it is also about domestic violence, poverty, rape, gender subordination, and ecological destruction (Sjoberg 2010). Feminism has put forward the prominence of the individual, particularly women, and society to be at the same level as the state and international organizations in security. 


\section{Women and peacekeeping operations}

Since the 2000, women have become a central part of the strategy for UN peacekeeping. Resolution 1325 emphasized the important of maintaining the equal participation of men and women in protecting world security as well as empowering gender in peacekeeping missions (United Nations 2016). Maximizing the role of women in peacekeeping operations is an attempt of the UN to deal with the impact of sexual abuse and human rights violations during conflict on the peacekeeping process. According to the UN, the involvement of women in peacekeeping missions could help the success of humanitarian assistance, especially that which is focused on women and children, up to and including better protecting them from sexual harassment. After the declaration of Resolution 1325 (2000), the UN Security Council has issued a further six resolutions to strengthen the role of women in peacekeeping operations. These resolution are resolution 1820 (2008), resolution 1888 (2009), resolution 1889 (2009), resolution 1960 (2010), resolution 2106 (2013), and resolution 2122 (2013). Through these new mandates, the United Nations has provided a great chance and space for women to prove their ability to maintain world peace and security.

As the United Nations aims to mainstream the integration of gender in all activities of peacekeeping operations, including decision-making, implementation as well as monitoring and the evaluation of the mission, the UN Department for Peacekeeping Operations (DPKO) has undertook three concrete efforts, which are: 1) the appointment of specialist gender advisors to a number of missions; 2) to increase the number of women leading and serving in peacekeeping operations; and 3) the provision of gender awareness training to its personnel (Lyytikäinen 2007). Therefore, in order to maximize these efforts, the UN established Gender Advisory Teams and gender training for UN peacekeeping forces (Lyytikäinen 2007). The Gender Advisory Team is a build committee that assists women who are participating in the peacekeeping processes, protecting them from sexual violence, helping the women to get involved in the electoral process and providing them support in the context of disarmament, demobilization, reintegration and legal courts. Moreover, the UN also provides gender training for their peacekeepers before they are deployed to the mission areas (Lyytikäinen 2007).

According to the United Nations International Research and Training Institute for the Advancement of Women (UN-INSTRAW), gender training is a requirement that should be undertaken by UN peacekeepers before they are deployed to the peacekeeping mission. It aims to improve their gender awareness, improve the effective implementation of the mandate and reduce any potential harmful behavior of the peacekeeping personnel that might collide with the mission policies. "Gender training 'is.[...] not a luxury, but a requirement for improving the effective discharge of the mission's mandate and reducing both harmful forms of behavior by the peacekeeping personnel and unintended negative effects of the mission policies and programmes' (Lyytikäinen 2007). As arranged by the $\mathrm{UN}$, gender training should be conducted at least twice both during the pre-deployment training program in the contributing country and once when they arrive to conduct the mission. The main basic or primary training of gender awareness is the responsibility of the UN contributor country before their troops depart. To what extend the training is received depends on the countries' policies and priorities (Lyytikäinen 2007).

Meanwhile, the UN DPKO Training and Evaluation Service (TES) complete the training by providing training materials for the use of its Member States, training advice and also supplementary training events. These services had been developed into a generic training package that is available online to all Member States (Lyytikäinen 2007). During the gender training, all peacekeepers receive training on non-technical issues, especially regarding how to prevent sexual exploitation and abuse. During the on-mission training, the program is quite different from what they receive in the pre-deployment training. In the on-mission training, every peacekeeping personnel member receives induction training with the military, and the police are trained separately from civilian staff. Moreover, the variations in the gender training included in the induction are also diverse from one mission to another. It tends to be stronger for peacekeepers that are placed on a mission that has gender advisers on the staff rota.

In terms of the number of personnel, through the efforts conducted by UN DPKO, there has been an improvement in the deployment of women peacekeepers. The number of women involved in UN 
peacekeeping keeps increasing. In 1993, only $1 \%$ of the total UN peacekeepers were women. But in 2014, the number increased to $3 \%$ of the military personnel and $10 \%$ of the police personnel, or around 125,000 women peacekeepers (United Nations 2016). Not only employed in the body of peacekeeping forces, women are also taking on the role of staff in the United Nations headquarters more. In 2012, around 48\% of the UN's staff were women (United Nations 2016). The rapid improvement of the role of women indeed shows their capability of being able work as good as man on peacekeeping missions. This has also been proven by the achievement of women as leaders in peace keeping. In 2014, Major General Kristin Lund from Norway was chosen to be the leader of UN peacekeeping activities in Cyprus (United Nations 2014).

As stated on the United Nations webpage, the involvement of women in peacekeeping has an important role. First, is to empower the women in the host countries where the peacekeeping is conducted. Second, women peacekeepers can be a mediator to address the specific needs of women ex-combatants during times of demobilization, assisting them in their reintegration with civil life (United Nations 2016). Third, they can help the peacekeeping forces to be more approachable. Fourth, is to help the UN when interviewing gender-based survivors of violence. Fifth, is to mentor female cadets in military or police academies. The last is to help peacekeepers to communicate with women in societies where they forbidden to speak to men. Another benefit from the involvement of women in peacekeeping is that they can reduce tensions and confrontations, improve access and support to local women, serve as a role model for women in society, provide greater security to the local population, particularly women and children, and improve the skill available while on UN peacekeeping missions (United Nations 2016). Considering all of these benefits, the UN has begun to improve the role of women in peacekeeping operations by encouraging all of its members to invoke women in their contingent in every UN peacekeeping mission, including the UN's current mission in Lebanon under the supervision of UNIFIL.

\section{Indonesian women peacekeepers in the UNIFIL}

As mentioned clearly on the UNIFIL's official web page on their history (UNIFIL 2016), the deployment of the UN Peace Force in Lebanon started in 1978 under Resolutions 425 and426 of the UN Security Council. This action was a response to the growing tensions and the conflict on the border of Israel-Lebanon in the early 1970s. The UN Security Council formed the United Nations Interim Force in Lebanon (UNIFIL) as a response to the Israeli invasion of South Lebanon, which became a military confrontation area between the Israeli government and Palestinian government. According to the official web page of the UNIFIL (2016), the deployment of UNIFIL forces to Lebanon had and still has three main purposes. First, is to supervise the withdrawal of Israeli troops from South Lebanon. Second, is to help to restore peace and international security as a result of the military conflict between Palestine and Israel. The third is to provide aid to the Lebanese government, aiming to restore power effectively in the region. Therefore, as an attempt to guarantee the creation of security in the region, a UN peacekeeping force has been stationed in Israel region to maximize the observation process.

However, three years after the deployment of UNIFIL on the border of Israel-Lebanon, commonly referred to as the Blue Line, the tasks of the UN peace force were limited to providing protection and humanitarian assistance to the local people. The thing is, even though Israel had pulled back its troops from the Lebanon area, the control by Israel through the Israeli Defense Forces and Lebanese de facto forces in the region was still sturdy. The UN Security Council is therefore tried to keep on conducting their observations, as well as maintaining the negotiations with the Israeli government in the hope that they would eventually withdraw from Lebanon. In July 2000, Israel started to pull back their military force. Following this retreat, in 2004, the UN Security Council updated the mandate of UNIFIL's operation through Resolution 1559.

Lebanon is not an area where peace can be easily created. Even though this area has been guarded and observed by the peace force, minor conflicts often happen in the Blue Line area which also often 
causes there to be victims on the side of the UN military observers. In 2006, the conflict rose again following the violation of disarmament by the Hezbollah group, which launched rockets into Israeli territory and also attacked several Israeli patrol troops. The increasing conflict between Hezbollah and Israel caused the UN Security Council to make Resolution 1701 (2006), which had the purpose of stopping the attacks conducted by both parties involved in the conflict.

Through the formulation of the resolution, the UN Security Council increased its force from 2,000 to 15,000 military personnel. According to the new mandate, there were several new aspects that had become tasks for the UNIFIL. This included monitoring the dispute termination between Israel and Hezbollah, giving assistance and support to the Lebanese Armed Forces (LAF) troops in the South Lebanon region, following the retreat of Israeli troops from the region, and coordinating activities between the Lebanon government and Israel. Their duties and responsibilities also included prolonging the humanitarian assistance in civil society and helping in the repatriation of displaced persons, giving an assistance to the LAF who were in the process of sweeping up the military forces in the region as been determined by the Lebanon government and UNIFIL, and also helping the Lebanon government to secure their border and entry points to prevent an inflow of unwanted parties (United Nations Department of Peacekeeping Operations 2002).

Since the formulation of Resolution 1701 in 2006, the mandate issued by the UN on UNIFIL's peace operations have always experienced developments and updates. Up until 2015, the UN Security Council had issued nine resolutions to strengthen and prolong the peace operations in order to help to maintain the peace in Lebanon (UN Security Council 2015). By maintaining peace in Lebanon, the UN also cooperates with military forces from other countries. There are 10,410 uniformed personnel, 279 international civilians, and 590 local civil staff members that have joined the UN peace force. The peace force in operation has also involved (and continues to involve) more than 30 states that have sent their military personnel and Indonesia is no exception (UN Security Council 2015).

Indonesia's peacekeeping forces joined the UNIFIL for the first time in 2006 and are still actively contributing. The Indonesian peacekeepers sent to the peacekeeping mission in Lebanon, in the early wave, was the Garuda Contingent XXII-A, or commonly called INDOBATT, which consists of 850 members of the Mechanized Infantry Batallion Task Force. The government of the Republic of Indonesia's policy when sending the Garuda Contingent to Lebanon was formed based on Presidential Decree No. 15 year 2006 (Indonesia Foreign Ministry 2016). The purpose was to help the UN peacekeeping force in maintaining peace and security in Lebanon. Indonesia is one of the most active contributor countries in Lebanon. In 2015, Indonesia was the $12^{\text {th }}$ largest contributor, with 1,290 peacekeeping personnel present in Lebanon, of which 24 of them are women (TNI AD 2016).

The first Indonesian woman soldier sent to the peacekeeping operation was Major Ratih, as a UN staff officer stationed in the Congo in 2008. In the beginning, there was only one woman representing Indonesia in the peacekeeping forces. In 2009, Indonesia sent another five women peacekeepers to join the UNIFIL with contingents from other countries. The numbers keep increasing, rising to 19 women personnel in 2014 and then 24 personnel in 2015 (TNI AD 2016). In 2009, the duty of Indonesian women peacekeepers has improved so then they are not only serving as staff officers. Their potential role has grown to include military staff, battalion staff, and military police officers. There are no differences of responsibility between male and female peacekeepers in UNIFIL. Both have the same duties and obligations as commanded by their chief.

Indonesian women peacekeepers also carry the same responsibility. In UNIFIL, Indonesian women peacekeepers are also in charge of field work including securing the area, guarding the observation posts, protecting civilians, guarding the contingent rotation, and investigating every violence case that might have been conducted by UNIFIL military personnel in the mission area. Although for now the involvement of Indonesian women UN peacekeepers is still low compared to men, but they have the same spirit when it comes to protecting world security and peace. This has been shown by the awards achieved by UN female peacekeepers given by the UNIFIL Force Commander, Major 
General Luciano Portolano, in March 2016 as a reward for their contributions in the UNIFIL (CNN Indonesia 2016). This positive achievement has become a great inspiration and influence on Indonesia increasing the number of women troops that it has sent to be a part of peacekeeping operations. The Indonesian government aims to improve the quality of their peacekeepers, not only in terms of personnel capabilities but also in the number of female personnel involved. The government has planned to increase the number of women in UNIFIL by up to 100 personnel. This plan is in line with the UN's demand that each Member States should deploy women troops that make up at least $10 \%$ of their contingent in one mission. Hence, the Indonesian government has the chance to more actively contribute to gender equality in peacekeeping operations. It is not an easy task, as it cannot be done without considering the character and culture of Indonesian society, which might influence the government's positive intention to deploy more women peacekeepers.

\section{Opportunities and challenges}

The implementation of Resolution 1325 (2000) by the UN on its Members States has had an impact on the structure of the peacekeeping forces. The uniformed peacekeeping personnel that used to be dominated by men now have the presence of women in their formation. How can a woman, who seems to be very weak, adhere to the activities mostly conducted by men? This hesitation has been argued by women who believe that they have ability to do what a man can do in security. The former UNIFIL Women Peacekeeper from Indonesia, Michiko Sanra Moningkey, argued that all women have the potential ability to deal with security issues such as those arising in peacekeeping operations (Moningkey 2015). According to Moningkey, in most cases during peace operations, women are more dependable when it comes to matters such as gathering information from the victims of sexual violation, managing women's prison, helping in the demobilization or reintegration of ex-combatants to civilian life, and other humanitarian activities needed in order to create sustainable peace. Moreover, she also stated that there are still plenty of duties and tasks undertaken by UNIFIL peacekeepers that need women's abilities. Indonesia has a positive chance to fulfill this need (Moningkey 2016).

The role of Indonesian women peacekeepers in the UNIFIL is not restricted to assisting women civilians in Lebanon, but they are also expected to conduct the same tasks that are given to male peacekeepers. There are some Indonesian women peacekeepers stationed as military police, as staff officers in the Joint Mission Analysis Centre (JMAC), as an Assistant Deputy Commanding Officer, as a health officer, and also as an officer in the Indonesian Battalion. In all of those positions in peacekeeping, Indonesian women can adjust to the environment very quickly. Indonesian women peacekeepers can perform their tasks as military personnel in a given operational area without considering their gender in the process. This shows that Indonesian women have the opportunity and ability to be the part of UN peacekeeping forces, side by side with male peacekeepers.

This does not mean that there are no challenges that can potentially hamper their intention to become peacekeepers. First, there is Indonesian culture. Indonesia is a country that has a culture that distinguishes between the role of women and men, including in the military scope. Although there are some women soldiers, their duties are different from men. It is rare for women to be directly involved in war or conflict. If they are military personnel, then Indonesian women only serve in the military offices. Therefore, on the peacekeeping missions, they are mostly stationed as staff officers, deputy assistants or clerical staff. This is different from other women peacekeepers such as female troops from Spain who are given positions of authority in machine companies or as military truck drivers (Moningkey 2016). According to Indonesian military commanders, women usually have an obligation to take care of their family and children. It would therefore be too risky for women to be involved in peacekeeping operations for as long as male peacekeepers.

The second challenge is regarding their physical capabilities. Women biologically tend to have less strength than men. This means that they have to work harder than men at physical activities. This condition is another hurdle for women peacekeepers when they have to adapt in mission areas, particularly when they have to adjust to the weather, physical environment, and any physical threats that might occur during the peacekeeping process. In addition, not like men, women also have specific 
biological issues that have to deal with while they are on a mission, which is not easy. The last thing is that women also have to be more controlled regarding their emotional issues. To be a peacekeeper means that they have to travel away from home. Women are more sensitive when they have to leave their family, more so than men (Moningkay 2015). All of these challenges have to be considered by women peacekeepers in order to encourage them to become more professional and competent at protecting security and peace.

Indonesian women have a great opportunity to prove their abilities in the security and peace sector. With the involvement of Indonesian women peacekeepers, it has been shown that Indonesia supports gender equality in peacekeeping operations, as mandated by the United Nations. Indonesia's contribution has become the way that Indonesia sees there as being the same potential for men and women to protect international security and maintain world peace.

\section{Conclusion}

The UN Security Council Resolution 1325 (2000) has opened up new possibilities for women to be actively involved in security matters. The participation of women peacekeepers in UN peacekeeping operations does not only maximize the effectiveness of UNPKO in addressing post-conflict reconstruction, but it also supports the consideration of gender issues as an integral part of security studies. The problem of sexual violence, harassment, and abuse that dominates post-cold war conflict has raised specific efforts from the United Nations to better engage with the role of women in conflict resolution. This consideration has also been implemented by the Indonesian government, by them deploying more women peacekeepers in Lebanon (UNIFIL). Indonesian women peacekeepers have the ability to help the UN when mediating and collecting information from the victims of sexual abuse, which cannot be done by male peacekeepers. This is at the same time as protecting and promoting gender equality in security. The involvement of Indonesian women peacekeepers in UNIFIL has ensured that there is a presence of women in peacekeeping operations, which is important during peace process.

Being a peacekeeper is not an easy task, particularly for Indonesian women. Their physical ability tends to be weaker than that of a man and there is the cultural quality that it is still odd for women to be engaged in the military and in combat, which has influenced the response of the Indonesian government and society in terms of women's involvement in peacekeeping missions. This point of view on the role of women in security has also had an impact on the duty of Indonesian women in Lebanon and any other UN peacekeeping mission. Different from the women peacekeepers from other countries such as Australia, Canada, Israel, and New Zealand - where their women peacekeepers have no restriction when it comes to serving on the frontline - Indonesian women peacekeepers are deployed to civic affairs. This shows that women still have not had much opportunity to prove their abilities in battle. Therefore, improvement is needed in order to increase the Indonesian women's peacekeeper role in peacekeeping operations.

\section{References}

ANTARANews (2012) Ibu Negara Lebanon puji Kontingen Garuda Indonesia. Oktober 10. [Accessed 2 September 2016]. http://www.antaranews.com/berita/337997/ibu-negara-lebanon-pujikontingen-garuda-indonesia.

BBC Indonesia (2014) Komandan Wanita Pertama Pasukan Perdamaian PBB. Mei 13. [Accessed 2 Oktober 2016]. www.bbc.com/indonesia/dunia/2014/05/140513_pbb_pasukan_wanita.

Bendix D \& Stanley R (2008) Engendering security sector reform: Where to from here?. Security and Peace 26 (1):44-48.

CNN Indonesia (2016) Prajurit Wanita TNI Terima Penghargaan Internasional. [Accessed 2 September 2016]. http://www.cnnindonesia.com/nasional/20160309144059-20-116395/ prajurit-wanita-tni-terima-penghargaan-internasional/. 
DCAF (2011) Gender and Security Sector Reform: Examples from the Ground. Paper compilation, Geneva: DCAF.

Detik News (2014) Kisah Tentara Wanita yang Menjadi Pasukan Perdamaian PBB. [Accessed 2 September 2016]. http://news.detik.com/berita/2774160/kisah-tentara-wanita-yangmenjadi-pasukan-perdamaian-pbb.

Hudson NF (2005) En-gendering UN peacekeeping operations. International Journal 60 (3):785-807.

Jakarta Globe Berita Satu (2012) Indonesia Wants More Female UN Peacekeepers. [Accessed 2 September 2016]. http://jakartaglobe.beritasatu.com/archive/indonesia-wants-more-femaleun-peacekeepers/.

Jimenez X (2012) Gender Perspective in United Nations Peacekeeping Operations. Pedagogical and teaching document, Williamsburg: Peace Operations Training Institute.

Kementerian Luar Negeri Indonesia (2015) Peraturan Menteri Luar Negeri Republik Indonesia Nomor 05 Tahun 2015 Tentang Peta Jalan Visi 4000 Personel Pemelihara Perdamaian 20152019. Berita Negara Republik Indonesia, Jakarta: Kementerian Luar Negeri Indonesia. [Accessed 26 September 2016].

Lyytikäinen M (2007) Gender Training for Peacekeepers: Preliminary overview of United Nations peace support operations. Gender, Peace \& Security Working Paper 4, UN-INSTRAW.

Moningkey MS (2016) TNI AU: Empat Medali Emas UNIFIL bagi Indonesia. [Accessed 2 September 2016]. https://ni-au.mil.id/pustaka/empat-medali-emas-unifil-bagi-indonesia.

Norville V (2011) The Role of Women in Global Security. Special Report 264, United States Institute of Peace.

Sjoberg L (2010) Gender and International Security: Feminist perspectives. London and New York: Routledge.

TNI AD (2016) Prajurit Wanita TNI Kontingen Garuda 2016 Rayakan Hari Wanita Sedunia di Lebanon. [Accessed 2 September 2016]. http://www.tniad.mil.id/index.php/2016/03/ prajurit-wanita-tni-kontingen-garuda-2016-rayakan-hari-wanita-sedunia-di-lebanon/.

UN OSAGI (2004) 2004 report of the Secretary-General on Women, Peace and Security. [Accessed 25 September 2016]. https://www.un.org/womenwatch/osagi/wps/sg2004.htm.

UNIFIL (n.d.) UNIFIL Troop-Contributing Countries. [Accessed 25 September 2016]. https://unifil. unmissions.org/unifil-troop-contributing-countries.

United Nations Department of Peacekeeping Operations (2002) Lebanon - UNIFIL Background. [Accessed 25 September 2016]. http://www.un.org/Depts/DPKO/Missions/unifil/unifilB. htm.

United Nations (2014) Meeting Coverage and Press Releases: Major General Kristin Lund of Norway Commander of United Nations Peacekeeping Force in Cyprus. [Accessed 25 September 2016]. https://www.un.org/press/en/2014/sga1468.doc.htm.

United Nations (2016) Peacekeeping Issues: Women in Peacekeeping. [Accessed 25 September 2016]. http://www.un.org/en/peacekeeping/issues/women/womeninpk.shtml.

United Nations (2016) Peacekeeping Operations: Women, peace and security. [Accessed 25 September 2016]. http://www.un.org/en/peacekeeping/issues/women/wps.shtml.

UNSC (2000) Resolution 1325 (2000). United Nations Web site. [Accessed 25 October 2016]. http:// www.un.org/en/peacekeeping/issues/women/wps.shtml. 